\title{
Rethinking Muslim women's equal rights: faith, property and empowerment ${ }^{1}$
}

\author{
M. Siraj Sait
}

The pursuit of gender equality and women's empowerment, especially in parts of the Arab and Muslim world, struggles in the face of several conundrums. How can women's civil and political rights be strengthened without corresponding attention to their socio-economic rights and poverty alleviation? How could women's participation in the public sphere be expanded when their private and intra-household leverage remains limited? How could Muslim women's rights be sustainable through secular discourse in traditional and religious communities? How can innovative formulations of women's rights be transformed into workable tools and embedded in formal systems for practical gains for Muslim women in complex environments? Recent developments and efforts in the arena of women's access to resources and property offer some fresh approaches to women's empowerment.

Among the estimated billion Muslim women across the world, the index of rights and empowerment dramatically varies reflecting the diverse political, economic, legal and religious systems and contexts. The interconnectedness and indivisibility between individual freedoms and economic development has been long asserted and established, for example, by Amartya Sen linking individual capabilities and economic opportunities (Sen 1999) and is apparent among Muslim communities. Most civil and political rights dimensions, from the choice of hijab (veil or head dress), to the right to drive, to exercise of sexual and reproductive rights, or the ability to be leaders, underpin socio-economic rights dimensions. Striking among the issues is the often-limited access to property, inheritance and land for Muslim women. Yet, it is acknowledged that property and land are vital not only for women's livelihoods, housing and economic opportunity but such rights also enhance their physical security from

1 This research is a part of research funded by the Global Land Tool Network, UNHabitat. 
violence, consolidates their control over their own resources and choices, and encourages their public participation.

The obstacles that Muslim women generally encounter in acquiring property and land are invariably similar to other patriarchal and hierarchical societies, but several distinctive aspects of tradition and Islamic law often intervene. On the positive side, Islamic law, including the holy Qur'an, proposes an extensive range of personal property rights for Muslim women that includes the rights to acquire, hold, use and dispose of property and land freely in her own name (Sait and Lim 2006, 134). Historical evidence points to Muslim women being propertied well before their Western counterparts (Moors 1996; Shatzmiller 1995). Yet, Muslim women often inherit only half the proportion of shares as their equally placed male relatives, though in some circumstances they inherit equally or more. Numerous economic and religious explanations abound for this gender discrimination, primarily that women have no economic responsibilities toward their family, which is the exclusive male role. However, unmarried women, women-headed households, as well as wives increasingly working shatter the myth of the exclusive male breadwinner with positive implications for gender equality in Muslim communities and innovative approaches to inheritance within the traditional framework.

In contrast to other areas of legal reform in the Muslim world, the gender differentiated Islamic inheritance rules have mostly endured. Most Muslim women abstain from challenging the apparent discrimination as the detailed fixed rules are derived from the verses of holy Qur'an (about 35 verses). Islamic inheritance is still widely practiced and a 'pride' of the community given the famous dictum attributed to the Prophet to, 'equal one half the sum total of human knowledge!' (Makdisi 1994). David Powers, however, rightly points out that rather than static automatic division of shares, Islamic inheritance is a broader and dynamic system of multi-stage negotiations and planning rather than just a body of technical rigid rules (Powers 1993, 13). A series of estate planning strategies as well as post inheritance negotiations and adjustments take place. Indonesia provides an example of parallel and simultaneous inheritance processes with the formal demarcation through Islamic inheritance accompanying a more need-based and equitable allocation in accordance with tradition (adat), which is lodged with the local land office.

While Muslim women are often only entitled to half the male share, there is nothing in Islamic law that prevents women from having equal property and rights. Muslim women frequently argue that inheritance should be viewed holistically through interlinked intra-family and intergenerational property flow systems, which compensate their inheritance deficit. There are no gender restrictions on women receiving property or land under the wasiya (will) that is permissible up to a third of an estate. Women can, and often do, receive biba (gifts) from family and outsiders at various stages in their life including marriage and beyond. There are other arrangements such as waqf (family 
endowments), which can theoretically be entirely for females. Associated with marriage are several payments including the mahr, which is payable by the bridegroom to the bride, payments as per the marriage contract, additional compensation for household work (iwad) maintenance during marriage and, in most countries, on divorce (nafaqa). In Iran, for example, women are entitled to wages for housework (ojrat-ol mesal). Islamic land laws also create genderneutral opportunities to acquire land rights through 'enlivening' unused land productively (mewat) or preemption (shufa). However, formal mechanisms to compensate women for their deficient inheritance rights are yet to be developed.

Inheriting Muslim women face two broad challenges. First, women mostly inherit cash, jewels or movable property while immovable property flows away from women generally. This reflects the global female land ownership estimated at around merely 3 per cent. In many countries, land is constructed to be a male domain and women further are considered as members of their husband's family who would take property away from the family. Fragmentation of land due to widespread inheritance thereby impacting on viability and economic efficiency of land parcels also targets women (Sait and Tempra 2014). Thus, ensuring that women have choice over what they inherit is equally important. Second, women often 'voluntarily renounce' (tanazul) their inheritance rights in 'exchange' for other property or to preserve family relationships with more powerful family members and retain access to the family home. This custom is the focus of legal reforms, for example, in Jordan and Palestine, where renunciation is to be registered with witnesses and takes effect only after a period. An interesting spin-off argument is that if women can renounce their inheritance shares in favour of male relatives, nothing prohibits the reverse to ensure gendered equal property rights.

While inheritance for Muslim women has received considerable attention, the denial of marital property to women in most Muslim countries has not. While Islamic law is admittedly strong on women's personal property and guarantees inheritance, it is silent on a Muslim wife's claim to her share of marital property - that which is acquired during marriage. For Muslim women without adequate savings, uncertain inheritance, swift divorces, inadequate dower (mahr) and limited maintenance (nafaqa), denial of their share in marital property renders them effectively destitute or reliant on natal family or the State. Without an independent stake in marital assets, she retains no property rights acquired or accessed or ownership interest in their marital home or land (Safwat 1995, 6).

Under a UN-Habitat funded project, research has explored the Islamic legal framework of marriage and property to demonstrate that Islamic law in itself does not inhibit equitable, if not equal, marital property distribution among spouses (Sait 2013a). More persuasively, in over a dozen countries where Muslims reside as majority (or in multi-religious countries), community property regimes or sharing of marital property is far more widespread among 
Muslims than assumed. The case studies of politically, geographically and jurisprudentially diverse Turkey, Kazakhstan, Indonesia, Malaysia, Morocco, Tunisia, Iran, Maldives, Tanzania, Kenya and South Africa underscore the complex but often accommodative relationship between marital property doctrines and Islamic principles. Furthermore, they offer opportunities for comparative legal reform in other countries.

Women's access to land is frustrated by the notion of the male as the head of the family. Hence property is legally registered in his name even if the woman has contributed directly or indirectly to the acquisition of the property. The traditional notion of the male as the head of the family has to be challenged. The University of East London produced provocative research showing that matrilineal kinship cultures (through the female line) and bi-lineal (through male or female) in Muslim communities are extensive (Sait 2013b). Dozens of case studies from various parts of the globe including India, Sri Lanka, Indonesia, Malaysia, Vietnam, Cambodia and Thailand, Algeria, Sudan, Burkina Faso, Ghana, Senegal, Kenya, Tanzania, Comoros, Mozambique and Malawi debunked the idea that Muslim women cannot be co-owners of property, if not head of the family. This is reflected in successful joint titling (where the names of male and females are registered) in several Muslim countries, including Indonesia. Encouragingly, several Muslim countries are moving away from the legal concept of the male as the head of the family; for example, the Mouduwana family code in Morocco (Aixelà Cabré 2007).

Several themes emerge from the analysis. Muslim marital property regimes are negotiated not merely from religious conceptions, but through its intersection with custom, family, kinship and the construction of property itself. In Muslim societies, legal pluralism prompts choices over marital property regimes between remnants of colonial law, modern constitutional and human rights provisions and Islamic, customary and secular laws. The varied legal reform methodologies of Muslim matrimonial property regimes include secularisation, Islamic re-interpretation, cohabitation of custom and Islamic law, and legal pluralism. Advocacy, research and legal reform recast Muslim women's rights but can remain paper aspirations that fail to materialise. Women are unable to assert their rights in the face of opaque or corrupt land registration systems or skewed land policies. Moreover, in their generalised form, women's property rights fail to support poor women on the specifics on how to access and retain land in the face of multiple challengers including land mafia, unscrupulous developers, official evictors or family competitors.

The Global Land Tool Network (GLTN) uses a tool-based approach to promote human rights and land security by developing tools that identify steps in interventions or mechanisms to deliver the objectives of human rights, outputs and outcomes. Through a multi-stakeholder process pro-poor, gendered and affordable tools are developed that indicate who does what where or when, providing information on substance, process and dispute resolution. 
For example, in relation to access to marital property, several tools are required, such as registration of marriage and marriage contract as well as enabling responsive institutions dealing with marriage and divorce. Remarkably, GLTN has adopted an 'Islamic Mechanism' whereby the Islamic dimension needs to be considered and used positively where applicable.

Land and property rights are not simply about ownership documents with female names. They encompass individual, collective and customary rights to access, use and manage property within a continuum of rights framework. Straddling civil and political as well as socio-economic rights, they potentially strengthen autonomy, offset vulnerabilities, increase choices, improve access to credit and economic opportunities and facilitate equal participation in all walks of life. In view of their significance, property rights are a complex and contested arena. Muslim property regimes are negotiated through intersection of custom, religion, family, kinship and the construction of property itself. Thus, the battles for Muslim women's equal rights are not merely fought on the streets, podiums and protest lines but also inside the homes, through religious interpretation and negotiations with all stakeholders. Drawing on comparative interdisciplinary studies and rights-based approaches within Muslim discourses, the endeavour to develop authentic, context-specific tools continues afresh.

\section{Bibliography}

Aixelà Cabré, Y. (2007) 'The Mudawwana and Koranic law from a gender perspective: the substantial changes in the Moroccan family code of 2004', Language and Intercultural Communication 7 (2), pp. 133-43.

Makdisi, J. (1984) 'Fixed shares in intestate distribution: a comparative analysis of Islamic and American Law', Brigham Young University Law Review Rev. 267 (3), pp. 267-304.

Moors, A. (1996) Women, Property and Islam: Palestinian Experiences -19201990 (Cambridge: Cambridge University Press).

Powers, D. S. (1993) 'Islamic inheritance system: a socio-historical approach', Arab Law Quarterly 8 (1), pp 13-29.

Safwat, S. M. (1995) 'What happens to the matrimonial home on divorce in Islamic law', International Legal Practice 20, pp. 1-12.

Sait, S. (2013a) 'Marital property in Muslim communities: Islamic law, custom and reforms', Recht van de Islam 27, pp. 33-53.

- (2013b) 'Women's property rights in Muslim matrilineal communities' Journal of Islamic State Practices in International Law 9 (1), pp. 1-35.

Sait, S. and H. Lim (2006) Land, Law and Islam: Property and Human rights in the Muslim World (London: UN-Habitat/ Zed Books). 
Sait, S. and O. Tempra (2014) Land Fragmentation in Muslim Communities:

Traditional Challenges and Innovative Consolidation Approaches

(Washington DC: World Bank).

Sen, A. (1999) Development as Freedom (New York: Knopf).

Shatzmiller, M. (1995) 'Women and property rights in Al-Andalus and the Maghrib: social patterns and legal discourse', Islamic Law and Society 2 (3), pp. 219-57. 